IP Periodica Polytechnica

Transportation Engineering

46(3), pp. 129-134, 2018

https://doi.org/10.3311/PPtr. 10392

Creative Commons Attribution (i)

RESEARCH ARTICLE

\section{Study of the Economic Cost of Road Accidents in Jordan}

\author{
Maen Ghadi ${ }^{*}$, Árpád Török ${ }^{1}$, Katalin Tánczos ${ }^{1}$
}

Received 10 December 2016; accepted 02 August 2017

\begin{abstract}
Traffic accidents in Jordan represent a serious problem, where every day about 2 persons die by road accidents, and the country loses between 2-3 percent of its gross domestic products (GDP) due to this problem. This research aims to estimate the total and unit costs (per crash severity and vehicle type) of road accidents in Jordan during three years (2011 through 2013) using human capital approach, and also to estimate the value of statistical life in Jordan for risk reduction of person's death by road accident using willingness-to-pay approach. The results revealed that Jordan is still suffering from a continuous rise in its road accidents' costs without a sufficient improvement accompanied with the dramatic increases in its number of vehicles and population (during the study period), especially after the crisis of Syrian refugees who enter the Jordan during this period. The estimated total costs of accident in the years 2011, 2012 and 2013 were about US \$ (3814, 4718 and 5146, respectively, which constituted 2.5\%, 2.3\% and $2.25 \%$ of the total country's GDP for the same years.
\end{abstract}

\section{Keywords}

Traffic Accidents, Loss of Output, Accidents Cost, Human Capital Approach, GDP

\section{Introduction}

Traffic accidents incur a large social and economic loses to countries, families and individuals. Every year about 1.2 million people dies by road accidents all over the world, and the world loss of about US \$ 518 billion (1-3\% GDP) annually due to this global problem (World Health Organization) (1). Traffic accidents in Jordan represent a serious problem, where about more than 2 persons die every day by road accidents and the country lose approximately $2-3 \%$ of its gross domestic product due to this problem.

During the last ten years the number of reported accidents in Jordan increased about 35\% from 70,266 crashes in 2004 to 107,864 crashes in 2013. And, the number of traffic accidents' fatalities had shown that; there are almost a constant number of fatalities in Jordan per year that ranged between 600 and 1,000 death, with the worst year recorded in 2007 of 992 deaths.

Road accidents problem in Jordan had a kind of fluctuation in its proportions during the successive three years 2011, 2012 and 2013, with still high number of crashes and fatalities. (See Table 1)

Table 1 Road accident statistics in Jordan (2011-2013)

\begin{tabular}{llll}
\hline \multirow{2}{*}{ Descriptions } & \multicolumn{3}{c}{ Year } \\
\cline { 2 - 4 } & 2011 & 2012 & 2013 \\
\hline Number of Accidents & 142,588 & 112,817 & 107,864 \\
Number of Fatalities & 694 & 816 & 768 \\
Number of Injuries & 18,122 & 17,143 & 15,954 \\
Registered Vehicles & $1,147,258$ & $1,213,882$ & $1,263,754$ \\
\hline
\end{tabular}

Source: Jordan Traffic Institute

Road crashes recently become one other major problem of the century. Most countries begin to highlight this problem and try to quantify its size by estimating its cost from economic and social perspective. Most of the countries around the world have an experience in costing traffic accidents that mostly depend on using human capital method. In Jordan a limited attempts were made to estimate accident costs. Al-Masaeid et al. (1999) has used the gross loss of output approach to estimate the total

\footnotetext{
${ }^{1}$ Department of Transport Technology and Economics, Faculty of Transportation Engineering and Vehicle Engineering, Budapest University of Technology and Economics, Stoczek st. 2, 1111 Budapest, Building ST, Hungary

*Corresponding author, e-mail: ghadi.maen@mail.bme.hu
} 
and unit cost of traffic accidents in Jordan in 1996 for three type of vehicles (passenger car, bus and truck) and resulted in US \$ 145 million loses with the highest percentage recorded for human loses. Another Thai study, conducted by Thailand Department of Highway (2007) adopted almost a similar gross loss of output approach to study the cost of road accidents in Thailand in 2004. The study provides a mathematical model with computer software for calculating traffic accident cost and resulted in US \$ 5.4 billion loses with high percentage recorded for loss quality of life cost of about $32 \%$ of the total cost. In the Middle East, Ismail and Abdelmageed (2010) has also used gross loss of output method for costing traffic accident in Egypt in the year 2008 based mostly on a data that updated from previous national literature by using inflation rate gotten from the national Central Bank's data resource. Typically, most applicant of Human Capital using the same cost items up to date; Sugiyanto and Santi (2017) achieved costs in Indonesia for human, property damages and other administration accident components. Recently, in several developed countries willingness to pay (WTP) approach has become an institutional accepted means for deriving monetary value of statistical life (VOSL). Le et al. (2011) has estimated WTP in Singapore by using a questionnaire survey targeted more than 4000 respondent and included both contingent valuation $(\mathrm{CV})$ and stated preference (SP) method. He reaches two main conclusions; firstly, people seem to find a difficulty in differentiating between low and high accident risk exposures. Secondly, there was a much higher ratio (1.64) between the resulted WTP value and the estimated loss of output value. On the other hand, although in most developed countries some consider WTP inappropriate due to widespread of market failure, but there are some good attempts made to utilize WTP in estimating accident costs. In Sudan, Mofadal et al. (2015) tries to estimate pedestrian accident cost in Sudan using CV-WTP approach using a questionnaire survey that included 1400 respondents. The result shows a VOSL for Sudan pedestrian ranged between US\$ 0.019 and US\$ 0.101 million. Some other researchers go beyond WTP's basic models. Zheng and $\mathrm{Wu}$ (2014) proposed a combined model based on the induced order weighted geometric average to elicit accident costs from predicted accidents in the future. However, it is important for any precise estimation method to have clear definitions for the different levels of accident's severities. For instance, DITRDLG (2009) define fatal accident as that result in a death within 30 days of accident occurrence. On the other hand, BITRE (2010) has divided non-fatal casualties into either hospitalized (person who need hospital treatment) or non-hospitalized casualties. Further classification has made by the Department of highway in Thailand (2007) to hospital casualties according to their level of disability. Ultimately, this research aims to highlight the problem of road accident in Jordan by estimate its total and unit costs during the years 2011 to 2013 using Human Capital approach as a best choice for this developing country, beside to adapting WTP approach in simple way for estimating (VOSL) of fatality by road accidents in Jordan as a first trial.

\section{Traffic Accident Cost Items}

Cost items could be differed from one study to another, but in general the cost of accidents using human capital approach can be grouped into three major components; human costs, property damages costs and general crash costs. The cost items in each component are shown in Table 2.

Table 2 Accident Costs by Human Capital Approach

\begin{tabular}{ll}
\hline & Fatality loss of output \\
& Disability loss of output \\
Injury loss of output (off-work cost) & Medical cost \\
Fuman Cost & Family and community loss cost \\
& Funeral cost \\
\hline \multirow{2}{*}{ Property Damage } & Vehicle repair cost \\
Cost & Vehicle detention period cost \\
& Non-vehicle property damage cost \\
\hline \multirow{2}{*}{ General Crash } & Travel time delay cost \\
Cost & Police work cost \\
& Insurance administration cost \\
\hline
\end{tabular}

\subsection{Human Costs}

Human costs estimation using human capital approach includes; lost output costs, medical care and emergency costs, quality of life cost (pain and suffering), family and community loss cost and funeral cost.

The value of loss of output: It's a value resulted from the loss of working time in the year of accident occurs, and/or in future years for the fatality and permanent disability injury. Lost output is an expression of society losses of the productive manpower, be it could be permanent or temporary.

Countries differ in estimating loss of output value due to some differences related to the economic wealth and type of data availability in each country. The methodology used in estimating output losses values are mainly based on using discounting method which used to convert all predicted future incomes into one present value, based on discounting rate (the difference in rate between the country's GDP rate and the interest rate) and the number of future production years lost.

The statistical data were collected mainly from Jordan traffic department the Insurance Commission of Jordan. The samples were included data of the medical cost, number of offwork days, pain and suffering compensation costs and first aid and transport costs for different casualties of different severity levels, ages and for both genders.

Loss of output values were estimated as follows:

- Long-term loss of output for death was estimated using discounted method considering the average national 
wage, that the death imaginary expected to earn through the rest of his/her productive age (15-60 in Jordan) if he/she doesn't die. This cost was estimated for different age groups for both genders separately, considering also unemployment rate as estimation for those who don't works or gain salaries.

- Disability loss of output represents those who lost part or full of their ability to work after the accident occurs. According to the available data injuries were divided into; slight injury medium injury and disability (un-recovery), the last was moreover divided into disability of three different percent; 0-25\%, 25-50\%, 50-100\%. However, the methodology of calculating disability loss of output is similar to that for death, but, with multiplying the unit present value of the per cent disability.

- Off-work loss of output is related to the number of days that the injury spent in hospital or at home for treatment and medical care until he/she full recovery and be able to work again with the same efficiency before the accident occurs. The methodology used is by deriving the average off-work days for each injury's severity level that obtained from samples, which shown that there are about 71, 48 and 23 off-work days lost per disability, medium injury and slight injury as an average, respectively.

- Community and family loss of output cost is associated with the activities that usually done by victims before being accident, whether to themselves or to their families and friends. A questionnaire survey was made of 411 respondents to investigate the average time they spent in social and family's works after their job time, such as, the amount of time that they spent in children care, study, participate in clubs and other works. The results show that the average time spent was about 4 hours of a standard 8 hour available per days. The methodology of estimating this cost is similar to that for death but, with considering the average social and family time lost.

Medical cost: This cost include medical treatment, hospital services and other related costs, and also include emergency services. The average medical costs were estimated of each casualty's severity level estimated from a random sample. However, the average unit medical cost per all casualties (including deaths) was estimated to be about US\$ 1155 including the emergency and first aid costs.

Pain and suffering cost: Accident's victim suffers from the lack of income and employment opportunities, including inability to pursue to happiness and entertainment in sport, or even have a normal social activity. His or her family also burden from accident when income losses or decrease by the victim. Some studies try to estimate this cost by conducting a survey that mainly directed to judges and lawyers according to their experiences in this matter. In the last years courts in Jordan priced pain and suffering of different casualty severity level based on several studies conducted in this manner. However slight injury was considered to have no pain and suffering cost.

\subsection{Property Damage Costs}

This cost is associated of damages caused to vehicle or by vehicles to other property that surround the accident location. Property damage involves three cost items; vehicle repairing costs, vehicle detention period costs and general crash costs.

Vehicle repair cost is directly associated to vehicle damage, which affect largely by type of vehicle involved in accident, crash severity and location of repair shop. While vehicle detention; is the time lost due to vehicle unavailable. For a public and commercial vehicle, e.g. bus, taxi or truck, the time means loss of business.

The total vehicle repair and detention costs in this study were collected from the Insurance Commission, while a survey involved 177 respondents was conducted to estimate unit costs that directed to people who had a previous accident experiences in the study years. The questions were clear and direct asking about type of vehicle that had an accident repairing cost and detention period time for their vehicles.

The average costs for each type of vehicles (passenger car, bus and truck) were estimated and then analysed with respect to the total costs (already available) to get a final estimation of the unit vehicle repairing costs, which estimated to be about US \$ (509, 576 and 743) per passenger car, bus and truck, respectively, with an average detention period 9 days for all type of vehicles. The detention period cost calculated for private and public (taxi) car separately, and for bus and mini-bus separately, beside to calculate it for trucks.

Estimation of non-vehicle property damages cost depended on the data available from insurance companies that represents only the total cost of this item, which accounts of about $2 \%$ of the total accident cost.

\subsection{General Crash Costs}

General crash costs in this study involved travel delay costs, police work cost and insurance administration costs.

Travel delay cost: Travel delay is caused by the accident to other vehicle that tries to pass the accident location, which result in a significant time penalty for those affected. Estimation of travel delay cost is somewhat difficult; because every crash is occur under different circumstances.

Identifying the delay caused by accidents can be a difficult task that full of complex information. Therefore, some researchers limited their task to study part of the problem. Sullivan (1997) study the impact of travel delay on a general freeway road. While Pereira et al. (2013) emphasize on predicting of the average clearance time between incident reporting and road clearance. Recently, the US (DOT/Volpe) Center in Cambridge (Hagemann, 2013) contracted with the Federal 
Motor Carrier Safety Administration to produce a simulation model for estimate pre-crash impacts of congestion from commercial vehicle crash using TSIS-CORSIM.

The methodology used in estimating delay adopt National Highway Traffic Safety Administration NHTSA (2015) model $(\mathrm{VC}=\mathrm{AAHT} \times \mathrm{CD} \times \mathrm{PLC} \times \mathrm{RCL})$. The model estimates the lost capacity due to congestion (VC) using vehicle hour as a unit measure (vehicle hour is a sum of the net delay for each individual vehicle affected). Therefore, the following assumptions were made:

- For calculating the average annual hourly traffic (AAHT) it is assumed that in Jordan most of the road are urban street with 2 lane works at capacity, therefore, AAHT is 2120 vehicle per hour (HCM).

- Crash duration (CD) is obtained by survey from Traffic Institute.

- Probability of lane closure (PLC) is equivalent to percent of accident subtracting roll-over accident divided by the total number of accidents for each crash severity level.

- Percent of blockage (RCL) to the road of accident direction is affected by the number of vehicle involved per accident.

- The percentage of passenger car, truck and vehicle in Jordan is assumed equivalent to its total number in Jordan as a whole, therefore we can note that bus experience the lower (vehicle hour) that related to the lower number of bus in Jordan.

- The resulted cost of delay per hour per each vehicle type is equivalent to detention period cost per hour (per standard 8 hours).

The following Table 3 shows the average of time delay (vehicle hour) per accident for each type of vehicle for different severity levels.

Table 3 Average delay per accident (vehicle hour)

\begin{tabular}{llll}
\hline \multirow{2}{*}{ Type of vehicle } & \multicolumn{2}{l}{$\begin{array}{l}\text { Accident severity level } \\
\text { (vehicle. hour) }\end{array}$} \\
\cline { 2 - 4 } & Fatal & Injury & PDO \\
\hline P. car & 1043 & 699 & 88 \\
Bus & 39 & 26 & 3 \\
Truck & 420 & 281 & 35 \\
\hline
\end{tabular}

Police work Cost: It is an indirect cost related to police activities for each reported accident that represent both fields an administration cost. This cost is estimated from an interviews and survey of Jordan Traffic Department police officers, and annual records of accident reports.

Insurance administration cost: This cost includes all of the administration activities and materials associated of the insurance companies, which found to had a unit cost per accident of about US\$ (185, 245 and 275) of the years 2011, 2012 and 2013 respectively. However, juridical and court costs are considered to be involved in insurance administration cost.

\section{Value of Statistical Life (Willingness-to-Pay)}

Human accident cost can be estimated using another method rather than lost output. The WTP approach is used to estimate VOSL or estimate value of risk reduction from deadly accidents. VOSL for death is considered to be equivalent to the lost output of death cost plus pain and suffering cost. A contingent valuation survey was applied on a sample of 411 respondents. The survey firstly obtained a personal information about the respondents (age, sex, educational level, job, individual monthly income), then it introduces the WTP part by a short introduction that define type and aims for that part of the survey. The questions explore how much the respondent will pay per year in order to reduce the risk of being killed in an accident for two different percentages (20\% and 50\%).

The resulted unit VOSL for risk reduction in Jordan was US\$ 376,387. It also found that this value is approximately equivalent to 2.23 times of that obtained from the human capital gross loss of output approach.

\section{Results}

Jordan incurred annually large losses from road accident. The cost per accident is found to be US\$ 3,814 in 2011, US\$ 4,718 in 2012 and US\$ 5,146 in 2013 (See Table 4). And, The total resulted losses from road accidents in Jordan for the years 2011, 2012 and 2013, as shown in table 5, are about US\$ 564.84 million, US\$ 547.00 million and US\$ 570.21 million, respectively, which represents of about $2.5 \%, 2.3 \%$ and $2.25 \%$ of its GDP for the same years, respectively.

Table 4 Unit accident costs for different severity levels in Jordan (2011-2013)

\begin{tabular}{|c|c|c|c|c|c|c|c|}
\hline \multirow{3}{*}{$\begin{array}{l}\text { Casualty } \\
\text { Level }\end{array}$} & \multicolumn{3}{|c|}{$\begin{array}{l}\text { Unit cost (US\$) per } \\
\text { year }\end{array}$} & \multirow{3}{*}{$\begin{array}{l}\stackrel{0}{D} \\
\stackrel{0}{0} \\
\frac{0}{0} \\
\frac{0}{0} \\
>\end{array}$} & \multicolumn{3}{|c|}{$\begin{array}{l}\text { Unit cost (US\$) per } \\
\text { year }\end{array}$} \\
\hline & $\bar{\Xi}$ & 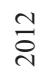 & $\stackrel{m}{\stackrel{n}{2}}$ & & $\overline{\bar{N}}$ & 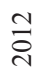 & $\stackrel{m}{\circ}$ \\
\hline & \multicolumn{3}{|c|}{ Unit Cost per Casualty } & & \multicolumn{3}{|c|}{$\begin{array}{l}\text { Unit Cost per Vehicle } \\
\text { Type }\end{array}$} \\
\hline Fatality & 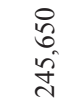 & $\begin{array}{l}\stackrel{+}{+} \\
\infty \\
\stackrel{+}{+}\end{array}$ & $\begin{array}{l}\infty \\
\stackrel{\infty}{N} \\
\infty \\
\sim \\
\sim\end{array}$ & نं & $\stackrel{\substack{\infty \\
\sim}}{\sim}$ & $\begin{array}{l}\infty \\
\infty \\
\infty \\
-1\end{array}$ & 호 \\
\hline $\begin{array}{l}\text { Serious } \\
\text { injury }\end{array}$ & $\begin{array}{l}n \\
\infty \\
m \\
\end{array}$ & $\frac{m}{m}$ & $\begin{array}{l}\bar{\sigma} \\
\hat{\sigma} \\
\hat{n}\end{array}$ & 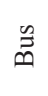 & $\begin{array}{l}\hat{\text { Dे }} \\
\text { ป̂ }\end{array}$ & $\begin{array}{l}n \\
\stackrel{n}{n} \\
\end{array}$ & $\begin{array}{l}\infty \\
\infty \\
\infty \\
0\end{array}$ \\
\hline $\begin{array}{l}\text { Slight } \\
\text { injury }\end{array}$ & $\stackrel{尺}{\stackrel{F}{=}}$ & 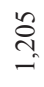 & సે & 总 & $\tilde{n}$ & $\begin{array}{l}\text { ㅁ } \\
\text { i }\end{array}$ & $\begin{array}{l}\infty \\
\infty \\
i\end{array}$ \\
\hline All & $\begin{array}{l}\infty \\
\stackrel{0}{0} \\
\stackrel{n}{n}\end{array}$ & $\begin{array}{l}\text { กิ } \\
\stackrel{n}{2}\end{array}$ & 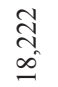 & $\bar{z}$ & $\stackrel{\hat{a}}{2}$ & 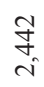 & $\stackrel{\infty}{\infty}$ \\
\hline
\end{tabular}


Table 5 Total accident costs in Jordan (2011-2013)

\begin{tabular}{|c|c|c|c|}
\hline \multirow{2}{*}{ Accident Cost Item } & \multicolumn{3}{|c|}{ Total cost (US\$) per year } \\
\hline & 2011 & 2012 & 2013 \\
\hline \multicolumn{4}{|c|}{ Human Costs } \\
\hline Fatality lost output & $95,708,054$ & $115,502,231$ & $124,740,194$ \\
\hline Disability lost output & $30,188,406$ & $23,481,195$ & $33,480,658$ \\
\hline $\begin{array}{l}\text { Injury lost output (off- } \\
\text { work) }\end{array}$ & $10,887,001$ & $10,669,430$ & $11,048,191$ \\
\hline Medical cost & $22,161,640$ & $19,898,973$ & $20,093,537$ \\
\hline Pain and suffering & $26,684,691$ & $28,300,286$ & $28,233,263$ \\
\hline $\begin{array}{l}\text { Community and family } \\
\text { losses }\end{array}$ & $76,637,949$ & $82,748,487$ & $94,760,653$ \\
\hline \multicolumn{4}{|c|}{ Property Damage Cost } \\
\hline Vehicle repair & $141,345,923$ & $134,979,304$ & $119,148,332$ \\
\hline $\begin{array}{l}\text { Vehicle detention period } \\
\text { cost }\end{array}$ & $59,204,749$ & $45,509,958$ & $49,525,244$ \\
\hline $\begin{array}{l}\text { Non-vehicle property } \\
\text { damage }\end{array}$ & $9,152,648$ & $8,237,092$ & $7,697,856$ \\
\hline \multicolumn{4}{|c|}{ General Crash Cost } \\
\hline Travel delay & $43,877,341$ & $33,931,056$ & $35,203,815$ \\
\hline Police works & $1,717,859$ & $1,572,819$ & $1,549,907$ \\
\hline $\begin{array}{l}\text { Insurance } \\
\text { administration }\end{array}$ & $26,351,250$ & $27,627,912$ & $29,644,894$ \\
\hline Total Cost & $543,917,509$ & $532,458,743$ & $414,026,545$ \\
\hline
\end{tabular}

\section{Conclusion}

1. Vehicle repairing cost comprise the largest cost item of about $25 \%, 25 \%$ and $21 \%$ of the years 2011, 2012 and 2013 respectively, and human fatality loss of output comprise the second largest cost of about $17 \%, 21 \%$ and $22 \%$ of the total cost for the same years, respectively.

2. Travel delay cost has seen to be a significant item that constitute of about $8 \%, 6 \%$ and $6 \%$ of the total cost during the years 2011, 2012 and 2013 respectively.

3. The Willingness-to-Pay approach was used in a simple way as a first trial in Jordan to predict the value of statistical life VOSL from the risk of being killed by road accidents, which had a value that equivalent to 2.23 folded of that obtained by the human capital approach.

4. There is slight fluctuation in the total estimated cost for the studied three years (2011-2013). Although, there were a decreases in the total number of accidents with years, but it didn't accompanied with similar decreases in the number of fatalities, which have also a significant effects on the total cost, as previously seen.

By comparing the resulted losses from road accidents obtained in this study in term of the per cent GDP $(2.5 \%, 2.3 \%$ and $2.25 \%$ ) with that obtained from a similar past study conducted in Jordan by Al-Masaeid (2.1\% of GDP losses) (5), we can note that; road accidents in Jordan still comprise a serious economic problem in compare with the country's limited resources, which may refer to the poor road safety policies applied during the past 20 years.

\section{References}

Al-Masaeid, H., Al-Mashakbeh, A., Qudah, A. (1999). Economic costs of traffic accidents in Jordan. Accident Analysis and Prevention. 31, pp. 347-357. https://doi.org/10.1016/s0001-4575(98)00068-2

BITRE (2010). Cost of Road Crashes In Australia 2006, BTRE Report 118, Bureau of Infrastructure, Transport and Regional Economics. Canberra, Australia. [Online]. Available from: https://bitre.gov.au/publications/2010/files/report_118.pdf [Accessed: 13th May 2016]

Department of Highways (2007). The Study of Traffic Accident Cost in Thailand. Faculty of Engineering, Prince of Songkla University, Thailand. [Online]. Available from: http://siteresources.worldbank.org/INTTHAILAND/Resources/333200-1177475763598/Sept07-traffic_accident-full-report.pdf [Accessed: 13th May 2016]

Department of Infrastructure, Transport, Regional Development and Local Government (2009). Road Deaths Australia, Monthly Bulletin. Australia. [Online]. Available from: http://www.infrastructure.gov.au/roads/safety/ publications/2009/pdf/rda_0609.pdf [Accessed: 13th May 2016]

Sullivan, E. C. (1997). New Model for Predicting Freeway Incidents and Incidents Delay. Journal of Transportation Engineering. 123(4), pp. 267-275. https://doi.org/10.1061/(asce)0733-947x(1997)123:4(267)

Pereira, F. C., Rodrigues, F., Ben-Akiva, M. (2013) Text analysis in incident duration prediction. Transportation Research Part C: Emerging Technologies. 37, pp. 177-192.

https://doi.org/10.1016/j.trc.2013.10.002

Hagemann, G., Hymel, K., Klauber, A., Lee, D. B., Noel, G., Pace, D., Taylor, C. (2004). Delay and Environmental Costs of Truck Crashes. U.S. Department of Transport, Federal Motor Carrier Safety Administration, Washington. (Report No. FMCSA-RRA-13-043). [Online]. Available from: https://ntl.bts.gov/lib/48000/48200/48200/Crash-Costs-Final-Report.pdf [Accessed: 17th May 2016]

Ismail, M. A., Abdelmageed, S. M. M. (2010). Cost of Road Traffic Accidents in Egypt. International Scholarly and Scientific Research \& Innovation. 4(6), pp. 1219-1225. URL: http://waset.org/publications/11781/cost-ofroad-traffic-accidents-in-egypt

Jordan Traffic Institute. (2011). Report of Traffic Accident. Jordan. [Online]. Available from: http://www.jti.psd.gov.jo/ [Accessed: 17th May 2016]

Jordan Traffic Institute. (2012). Report of Traffic Accident. Jordan. [Online]. Available from: http://www.jti.psd.gov.jo/ [Accessed: 18th May 2016]

Jordan Traffic Institute. (2013). Report of Traffic Accident. Jordan. [Online]. Available from: http://www.jti.psd.gov.jo/ [Accessed: 15th May 2016]

Le, H., van Geldermalsen, T., Lim, W. L., Murphy, P. (2011). Deriving Accident Costs using Willingness-to-Pay Approaches - A Case Study for Singapore. Australasian Transport Research Forum. [Online]. Available from: http://atrf.info/papers/2011/2011_Le_Geldermalsen_Lim_Murphy.pdf [Accessed: DAY MONTH YEAR]

Mofadal, A., Kanitpong, K., Jiwattanakulpaisarn, P. (2015). Analysis of pedestrian accident costs in Sudan using the willingness-to-pay method. Accident Analysis \& Prevention. 78, pp.201-211. https://doi.org/10.1016/j.aap.2015.02.022

National Highway Traffic Safety Administration. (2015). The Economic and Societal Impact of Motor Vehicle Crashes, 2010 (Revised). Annals of Emergency Medicine. 66(2), pp. 194-196. https://doi.org/10.1016/j.annemergmed.2015.06.011 
Sugiyanto, G., Santi, M. (2017). Road Traffic Accident Cost using Human Capital Method (Case Study in Purbalingga, Central Java, Indonesia). Jurnal Teknologi. 79(2), pp. 107-116.

https://doi.org/10.11113/jt.v79.5375

World Health Organisation (2009). Global status report on road safety: time for action. Geneva. [Online]. Available from: http://apps.who.int/iris/bitstre am/10665/44122/1/9789241563840_eng.pdf [Accessed: 15th May 2016]

Zheng, J., Wu, X. (2015). Prediction of Road Traffic Accidents Using a Combined Model Based on IOWGA Operator. Periodica Polytechnica Transportation Engineering. 43(3), pp. 146-153.

https://doi.org/10.3311/pptr.7499 